\title{
The representation of male characters in three challenging picture books: A multimodal study ${ }^{1}$
}

\author{
Arsenio Jesús Moya-Guijarro - University of Castilla-La Mancha \\ arsenio.mguijarro@uclm.es
}

Rebut / Received: 04/02/20

Acceptat / Accepted: 06/04/20

Resumen. La representación de personajes masculinos en tres libros álbum desafiantes. Un estudio multimodal. El objetivo de este artículo es analizar cómo las metonimias visuales contribuyen a retar estereotipos de género en tres libros álbum. La semiótica social multimodal (Kress \& van Leewen, 2006; Painter, Martin \& Unsworth, 2013), y la lingüística multimodal cognitiva (Forceville, 2009 y Pinar, 2015) son los enfoques adoptados para llevar a cabo esta investigación. Las funciones discursivas de las representaciones metonímicas se analizan en base a cómo los dominios fuente se proyectan en los dominios meta en los contextos en los que las metonimias se construyen. Los resultados revelan que las representaciones metonímicas son utilizadas esencialmente en los libros álbum para adscribir cualidades negativas a personajes anclados en estereotipos de género, poner al lector del lado de los personajes masculinos principales y, finalmente, crear expectativas en momentos importantes de la narración.

Palabras clave: multimodalidad, representaciones parciales o metonímicas, libros álbum, género.

Abstract. The representation of male characters in three challenging picture books: A
multimodal study. The aim of this paper is to analyse how visual metonymies contribute to the
challenging of gender stereotypes in a sample of three picture books. Multimodal social semiotic
(Kress \& van Leewen 2006, Painter, Martin \& Unsworth 2013), and cognitive approaches
(Forceville, 2009 and Pinar, 2015) have been adopted to carry out this research. The discourse
functions of part/whole representations are determined by analysing how their source domains

1. The research reported in this article was carried out within the research project FFI2017-85306-P (The Construction of Discourse in Children's Picture Books, funded by the Spanish Ministry of Economy, Industry and Competitiveness. 
are projected onto their targets in the context where they are to be construed. The results reveal that metonymic representations are essentially used in the picture books featuring boys to ascribe negative qualities to characters, put the reader on the side of the main male characters and, finally, create expectations at important moments in the plot.

Keywords: multimodality, part-whole /metonymic representations, picture books, gender.

\section{Introduction}

Most of the research carried out in relation to gender issues and children's picture books has essentially centred on quantitative questions of content, that is, on the number of male and female characters that appear in the stories or the frequency with which they play a leading or a secondary role (Sunderland, 2012; Taylor, 2003). The results found in this regard are relevant. Male characters outnumber females in these children's narratives written in English, both in the linguistic mode and in the illustrations, an aspect that has implications for the gender image that is may be constructed by the child. Women and girls are usually not sufficiently considered in books intended for this child audience.

Although the research carried out on picture books and gender from a content perspective is certainly conclusive, it is also true that despite the multimodal nature of picture books, not enough attention has been paid to the meaning that comes from the interaction of images and words in these literary works (Barton \& Unsworth, 2014; Martínez-Lirola, 2019). In this sense, Sunderland (2012) highlights the need to adopt multimodal approaches that complement the traditional narrative theories, focussed essentially on the study of the written language, to analyse contemporary narratives properly. Multimodal approaches seem to be necessary to analyse how images and words are combined together to create meanings which are beyond the scope of each semiotic mode in isolation (Moya-Guijarro, 2014). There are still few studies (Sunderland \& McGlashan, 2012) are an exception) that examine a sample of children's picture books united by a specific topic and communicative purpose; in our case, visual narratives that challenge gender stereotypes and promote gendered discourses.

In addition, with the exception of some works by Moya-Guijarro (2013, 2019), the genre of picture books has been practically unexplored within the framework of cognitive linguistics, which provides interesting resources to analyse multimodal discourses through the tropes of metaphor and metonymy (Forceville, 1996, 2009). Moya-Guijarro's (2019) research shows that, unlike metaphors, whose occurrence in picture books are null or scarce, metonymic depictions of characters (Painter, Martin, \& Unsworth, 2013) arise quite frequently in visual narratives, specifically when it comes to representing them at important moments in the story. Moreover, as metaphors and metonymies behave differently depending on the genre in which they are used (Forceville \& Urios-Aparisi, 2009), it is important for the theorization of visual tropes to consider 
their occurrence in a variety of genres and analyse how these, in combination with verbal language, create meaning in specific contexts. (Forceville, 2009; Pinar, 2015).

In order to develop the analysis on children's stories and gender carried out so far, this study approaches picture books from a combined multimodal social-semiotic and cognitive perspective, and explores the meaning potential of part/whole representations of characters in a sample of three picture books which feature boys who do not conform to macho stereotypes and promote gendered discourses (see sample texts, section 3.1). Specifically, I aim to establish how visual metonymies, in combination with verbal language, contribute to challenging gender stereotypes in the sample texts. The study also determines whether complete depictions of characters necessarily precede their visual metonymic representations, as they show all the basic features of the depicted characters in the illustrations, without omitting any essential part. Complete depictions have been claimed to help young readers recognize and identify the main characters in the stories (Painter et al., 2013).

The frameworks applied to carry out this research are Painter et al.'s (2013) semiotic approach to picture book and multimodal cognitive linguistics, essentially developed by Forceville (2009). The integration of both cognitive and social-semiotic approaches to study multimodal artefacts has already been proposed by other researchers, such as Feng and O'Halloran (2013), who have developed a multimodal framework to explain how characters' emotions are represented in films. Feng and O'Halloran (2013) also demonstrate how the integration of social semiotics and cognitive approaches to metaphor and metonymy is significant for the exploration of multimodal discourse. Painter et al's (2013) social-semiotic approach provides an account of systematic options to identify metonymy-based visual elements in character depictions in visual narratives, while Forceville's (2009) cognitive perspective works on cognitive aspects to identify the communicative functions of metaphors and metonymies in multimodal discourses. The combination of these two approaches allows us to identify patterns of correlations between metonymic representations and their communicative impact in the context where the visual tropes are generated and used.

The article is structured in four parts. The theoretical frameworks adopted, multimodal social semiotics and cognitive linguistics, are described in section 2 . In section 3 the sample texts chosen for analysis and the methodology are presented. The part-whole representations of characters in the stories are analysed in this section. Part 4 is devoted to the conclusions, where I show how monomodal visual metonymies are useful representation strategies used by illustrators to promote gender equality and respect for diversity ${ }^{2}$.

2. Monomodality implies the use of only one semiotic mode to encode reality. In monomodal metonymies the target and the source domains are represented through only one semiotic mode, be it the verbal or the visual (Forceville, 2009). 


\section{Literature Review}

Kress and van Leeuwen (2006 [1996]) have developed a method of social semiotic analysis of visual communication, based on Halliday's (1978, 2004) social semiotics, in which they assign representational, interpersonal and compositional meaning to images. Thus, any image, beyond representing the world (representational metafunction), also plays a part in some interaction (interpersonal metafunction) and constitutes a recognizable and coherent kind of text (textual metafunction; see also Barton \& Unsworth, 2014). In spite of having built on Kress and van Leeuwen's (2006) visual grammar as an invaluable framework for the study of images, Painter et al. (2013) consider that their account is not sufficiently developed to study certain aspects of picture books, essentially those concerning participant manifestations, inter-events relations in successive and simultaneous images, circumstantiation, focalization and emotional engagement. ${ }^{3}$ They extend Kress and van Leeuwen's visual grammar and develop further systems at representational, interpersonal and textual levels of analysis to deal with images in picture books.

Regarding representational meaning (Halliday, 2004), which is of interest to us here, Painter et al. (2013) propose a system of character manifestation for visual narratives, whose main options are shown in Figure 1. Two basic and simultaneous options are initially distinguished within the system of character manifestation: complete and metonymic depictions. The latter is, in turn, subdivided into two subclasses: body part (excluding head) and shadow / silhouette (Painter et al., 2013). A complete depiction implies the representation of a character including face or head, which are essential for recognition. However, a metonymy involves a visual representation of a character realized by the depiction of only a body part, a silhouette or a shadow. The body/part relation is used when a part of the body is depicted, excluding the head. The shadow / silhouette alternatives come into play if only a shadow or a silhouette of the character is shown (see figure 1).

A character is inferred to have the same identity as one previously depicted if the most recognizable features of his or her appearance (head, face) are reproduced in subsequent images. If the character is represented metonymically through a part/whole relation, a shadow or a silhouette, the inferences viewers have to make to identify him are more complex, as his or her basic features (face and hair), which aid recognition, may be absent (Painter et al., 2013). Therefore, metonymies seem to require more inferences on the part of the child reader than complete manifestations when he or she faces the task of tracking participants in a story (Moya-Guijarro, 2019).

3. In this article the attention is focused on the system of character manifestation shown in Figure 1. For the systems of focalization, emotional engagement, inter-events and circumstantiation, see Painter et al. (2013), pages 30, 35, 71 and 79, respectively. 


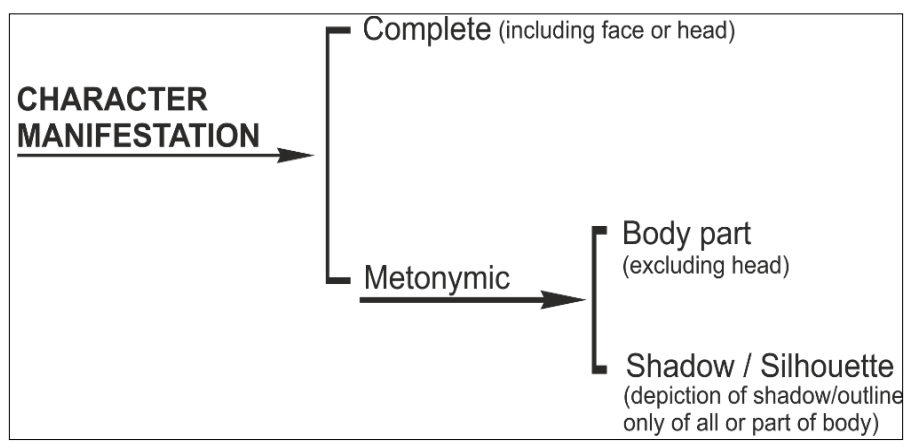

Figure i. System of character manifestation (Painter et al., 20i 3, P.6i).

In the previous paragraphs, metonymy has been outlined from a purely socialsemiotic perspective (Painter et al., 2013). However, this trope can also be explored from a cognitive approach, which complements the features attributed to metonymy so far. One of the concepts that has probably aroused most interest within cognitive linguistics is the theory of conceptual metaphor, initially proposed by Lakoff and Johnson (1980), and later developed by Lakoff (1987), and Ruiz de Mendoza and Díez (2002), inter alia.

Cognitive linguists assume that metaphors, in addition to metonymies, are conceptual mechanisms which may be used to represent abstract phenomena in terms of concrete elements (Lakoff 1987; Lakoff \& Johnson, 1980). Although cognitive scholars have shown interest mainly in the verbal metaphor, in recent decades the metonym has also been a focus of study by renowned linguists such as Barcelona (2002) and Hidalgo and Kraljevic-Mujic (2011). These authors have based their research mainly on written language. However, in recent decades the study of non-verbal manifestations of visual tropes has been arousing more interest. Forceville's (2009) study on non-verbal metonymy in visual and audio-visual discourse is evidence of this. In subsequent works on visual tropes, Forceville (2009) highlights that the metaphor and metonymy can be manifested not only verbally, but also visually and multimodally.

Unlike verbal tropes, multimodal metaphor and metonymy are conceived as cognitive tropes in which the source and the target domains are essentially represented completely or predominantly by different semiotic modes (Forceville, 2006). Through the metaphor an (abstract) entity or concept, which functions as a target (e,g, life in Life is a Journey), is understood and represented mentally via another referent or (more concrete) concept, the source, which belongs to a different domain (journey) (Lakoff \& Johnson, 1980). In the case of metonymy, the source and the target, however, are experienced as parts of the same conceptual domain. Examples of metonymic relations are: a part for the whole (More hands [doctors] are needed in Spain to beat Coronavirus), the whole for one of its parts (My boiler [the boiler pressure relief valve] has broken down), a place for institution 
(The White House [US government] has declared the Coronavirus a pandemic), Author for Book (Gongora is difficult to read), etc. In turn, Ruiz de Mendoza and Díez (2002) distinguish between target-in-source and source-in-target metonymies. Whilst in the former a superordinate or matrix domain (source) represents a subdomain (target) as in Pill for Contraceptive Pill in 'she is on the pill'), in the latter (Hands for Sailors in 'all hands on deck') a subdomain (source) establishes a metonymic relationship with a matrix domain (target). Ruiz de Mendoza and Díez (2002, p. 495-499) state that target-in-source metonymy involves a "domain reduction" while the source-in-target metonymy is understood in terms of "domain expansion."

Forceville (2009, p. 58) affirms that "the choice of metonymic source makes salient one or more aspects of the target that otherwise would not, or not as clearly, have been noticeable, and thereby makes accessible the target under a specific perspective [...]." Therefore, there is always a reason for a speaker/visual artist to use a metaphor or a metonymy in a specific context of communication, and this reason can be identified in terms of relevance (Sperber \& Wilson, 1985) and communicative intention (Forceville, 2009). So, the use of a metonymy in a specific context often implies a change in salience and perspective, as will be shown in section 3. Another aspect that Forceville (2009) highlights with regard to metaphor and metonymy is that these tropes are contextually and culturally dependent concepts, since they can only be understood and interpreted within the cultural and situational contexts where they are created and used.

\section{The analysis of part/whole character representations}

Now that the theoretical frameworks have been described, in this section I introduce the sample texts chosen for analysis and outline the methodology adopted to explore the metonymic character depictions in the picture books featuring boys as main characters.

\subsection{Sample texts}

Three picture books written in the late $20^{\text {th }}$ Century and the first years of the $21^{\text {st }}$ Century were chosen as sample texts to analyse the full potential of metonymies in children's stories where images and words co-exist: Willy the Champ by A. Browne (2008), Prince Cinders, written and illustratedby B. Cole (1997), and 10,000 Dresses by M. Ewert and R. Rex (2008), the first transgender picture book for children. The visual narratives are original stories which stand out for their literary quality, an opinion that has been shared by critics (Hamilton et al., 2006, McCabe et al., 2011, and Sunderland, 2012), and specialized journals such as Children's Literature in Education, Sex Roles and Gender and Society, inter alia).

Although the picture books analysed feature different stories and situations, all of them defend freedom and social acceptance, independently of people's preferences and sexual orientation, an aspect that has primarily determined their selection. Overall, the 
three picture books that comprise the sample texts share a scathing review of gender stereotypes and identities. Indeed, the three stories portray children who do not necessarily conform to the macho stereotypes typically associated with their gender in traditional narratives. Hence, Willy the Champ features an anthropomorphic ape half the size of his peers who is tirelessly trying to catch up with the rest in sports events, though in vain. Nonetheless, his determination to preserve leads him to beat, although quite by chance, Buster Nose, the neighborhood bully. As a result, he is finally cheered and acclaimed as the Champ. Similarly, 10,000 Dresses features Bailey, a boy who feels like a girl inside cannot count on his family's support to deal with his inner struggle: his desire to wear a dress. Finally, Prince Cinders tackles the issue of gender stereotypes from the perspective of a small and scruffy prince who is always teased by his three big, strong brothers who make him clear up all their mess. The story is a retelling of the classic fairy tale, Cinderella.

\subsection{Methodology}

As stated in the introduction, in the current study I combine the social semiotic (Painter et al., 2013) and cognitive accounts (Forceville, 2009; Pinar, 2015) to examine the visual realizations of metonymies in a sample of three picture books which manifest progressive gendered discourses. Firstly, I have identified the ideation al choices (complete or metonymic) available to the illustrator to represent characters in picture books. Painter et al.'s (2013) system of character manifestation with the different options (body part, shadow or silhouette for the whole character), outlined in Section 2, has been considered to identify the metonymic representations of characters in the tales. Once the visual metonymies have been identified, I have analysed their discourse functions, that is, their communicative functions in the contexts where they are produced in order to find out which communicative motivations may have led the illustrators to use them in the stories. To identify the metonymies' communicative functions I have analysed how their source domains are projected onto the targets, the characters themselves, in the context where the tropes are used, leading viewers, both young children and adults, to specific meaning extensions and personalized inferences.

\subsection{The analysis}

In the three visual narratives featuring boys, several characters are sometimes depicted metonymically, since one of their parts is used to infer their whole. Nine metonymies have been counted, an average of three metonymies per picture book. The metonymies identified in the three stories are indicated in Table 1. For reasons of space, in what follows I comment on those that play a key role in the development of the plots. 
TABle I. PART/WhOlE METONYMiC REPRESENTATIONS IN THE SAMPLE TEXTS

\begin{tabular}{|c|c|}
\hline Metonymy & $\begin{array}{l}\text { Function (in combination } \\
\text { with verbal language) }\end{array}$ \\
\hline \multicolumn{2}{|c|}{ Willy the Champ (1 metonymy) } \\
\hline $\begin{array}{l}\text { Gorilla's shadow standing for Buster, the } \\
\text { intimidating Bully ( } 8^{\text {th }} \text { double spread). }\end{array}$ & $\begin{array}{l}\text { Anticipate a new and threatening character } \\
\text { in the story and intensify Buster's threat to } \\
\text { Willy. Put the reader on Willy's side. }\end{array}$ \\
\hline \multicolumn{2}{|c|}{ Prince Cinders ( 2 metonymies) } \\
\hline $\begin{array}{l}\text { Lower legs and feet of a girl and a boy } \\
\text { standing for Prince Cinders and his fairy } \\
\text { godmother ( } 4^{\text {th }} \text { double spread). }\end{array}$ & $\begin{array}{l}\text { Make fun of Prince Cinders' dirty } \\
\text { godmother. }\end{array}$ \\
\hline $\begin{array}{l}\text { Tail and back leg of an animal for Prince } \\
\text { Cinders' cat }\left(6^{\text {th }} \text { double spread }\right) \text {. }\end{array}$ & Create irony in the story. \\
\hline \multicolumn{2}{|c|}{ 10,000 Dresses (6 metonymies) } \\
\hline $\begin{array}{l}\text { Two arms and hands holding a pair of } \\
\text { scissors standing for Bailey's mother ( } 4^{\text {th }} \\
\text { double spread). }\end{array}$ & $\begin{array}{l}\text { Show Bailey's mother's preoccupation with } \\
\text { her own business.... and lack of attention } \\
\text { to her son. }\end{array}$ \\
\hline $\begin{array}{l}\text { Half head, back and part of legs of a } \\
\text { woman standing for Bailey's mother }\left(5^{\text {th }}\right. \\
\text { double spread). }\end{array}$ & $\begin{array}{l}\text { Highlight Bailey's mother lack of contact } \\
\text { to her son and lack of attention to his real } \\
\text { desire: making dresses. }\end{array}$ \\
\hline $\begin{array}{l}\text { Part of arms and hands pulling up weeds } \\
\text { standing for Bailey's father ( } 7^{\text {th }} \text { double } \\
\text { spread). }\end{array}$ & $\begin{array}{l}\text { Suggest the idea that Bailey does not find } \\
\text { support from his father either, who is also } \\
\text { involved in his own activities and does not } \\
\text { care for the child's real desires. }\end{array}$ \\
\hline $\begin{array}{l}\text { Trunks and legs of three people standing } \\
\text { for Bailey's brother and his friends }\left(9^{\text {th }}\right. \\
\text { double spread). }\end{array}$ & $\begin{array}{l}\text { Emphasize the lack of contact between } \\
\text { Bailey and his brother and the lack of } \\
\text { attention the older brother pays to Bailey. }\end{array}$ \\
\hline $\begin{array}{l}\text { Arms and hands of a boy holding a ball } \\
\text { standing for Bailey's brother }\left(10^{\text {th }} \text { double }\right. \\
\text { spread). }\end{array}$ & $\begin{array}{l}\text { Highlight the lack of contact between } \\
\text { Bailey and his brother and the lack of } \\
\text { sensitivity towards Bailey's real desire. }\end{array}$ \\
\hline $\begin{array}{l}\text { Hands holding a needle standing for } \\
\text { Bailey's new girlfriend, Laurel ( } 11^{\text {th }} \text { double } \\
\text { spread). }\end{array}$ & $\begin{array}{l}\text { Introduce a new character in the story } \\
\text { who shares the same interest as Bailey and } \\
\text { accepts his true personality. }\end{array}$ \\
\hline
\end{tabular}

A part-whole metonymy that is worth mentioning is identified in Willy the Champ. The tale portrays Willy, a sensitive chimpanzee who likes reading, listening to music and going to the cinema with his friend Milly. However, he is not good at sport or 
swimming. One day he is threatened by a horrible, strong character, Buster Nose. This threat is anticipated in the story by the metonymy, shadow (source domain) standing for Buster Nose (target domain), who is not completely depicted until the following double spread, the thirteenth. The shadow of the intimidating bully projects onto Willy, as yet unaware of the danger he will face (see Figure 2). The metonymy shadow for Buster anticipates the new and threatening character in the story and intensifies the threat of Buster to Willy, as he is described in the verbal mode as a "horrible figure". In addition, the shadow is dark and experientially a premonition of impeding danger. The darkness of the shadow, together with the scared faces of the gorillas accompanying Willy, anticipates the threat the protagonist of the story will have to face on the following double spread when he is attacked by Buster Nose, the neighborhood bully.

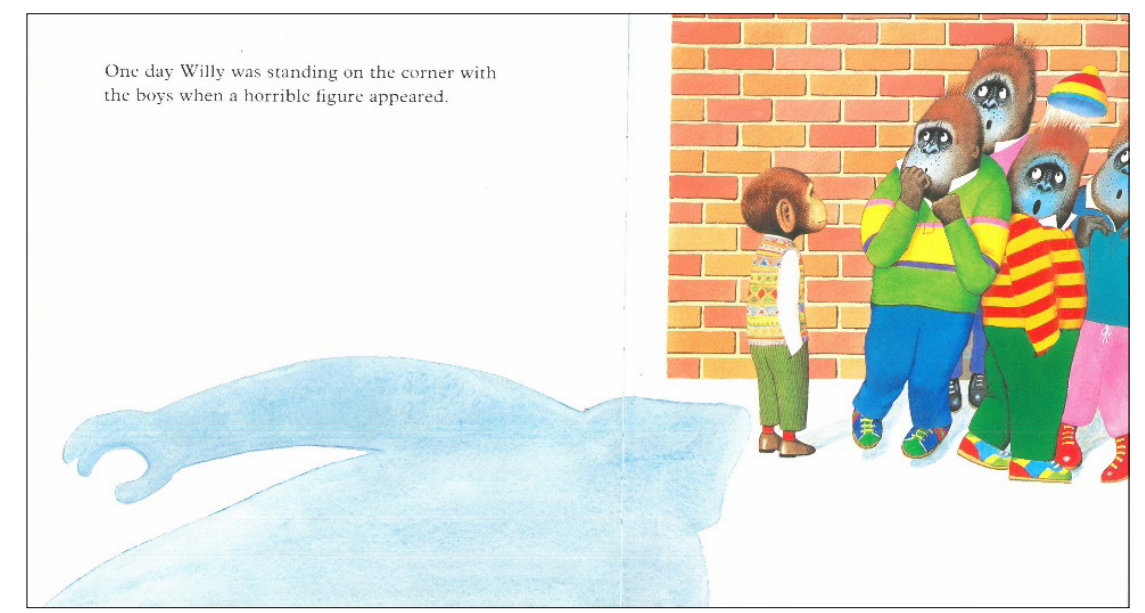

Figure 2. A Shadow for Buster Nose. Illustration from Willy THE CHAMP by Anthony Browne. Reproduced by kind permission of Anthony Browne.

Contrary to the expectation that complete manifestations of characters usually precede metonymic depictions (Painter et al., 2013), in this tale a secondary character, Buster Nose, is activated through a part/whole metonymy before he is depicted in full in the following illustration. This makes his appearance even more threatening and scary (Moya-Guijarro, 2019). Although Willy the chimpanzee must go through difficult situations, in the end he accidentally manages to defeat Buster and gains respect from the big chimpanzees who had jeered at him. As Moya-Guijarro and Pinar (2008) state, animal characters are frequently used and transformed into anthropomorphic beings with human attributes and feelings in children's stories, as is the case of Willy the Champ. Willy, the male protagonist, is able to speak, think and transmit feelings such as sadness or happiness. He also adopts human poses. The depiction of the story protagonist as an animal gives the illustrator the freedom 
to eliminate various issues that are otherwise essential in an assessment of a character, for example: age, race, social status, etc. In this way, any child can easily identify with the depicted participant.

Another two source-in-target metonymic depictions have been counted in Prince Cinders by Babette Cole. The story portrays a scruffy and skinny boy, Prince Cinders, always teased by his three big hairy brothers. Prince Cinders's brothers, smartly dressed, go the palace disco with their princess girlfriends. Meanwhile they make poor Prince Cinders stay behind cleaning up after them. One night a dirty fairy falls down the chimney, telling him that all his wishes shall be granted. Contrary to the readers' expectations, she does not seem to be that powerful. When she tries to turn an empty can into a big car to take Prince Cinders to the Palace disco, she just gets a small toy car. It is precisely at this point when Cole, the illustrator, uses a metonymic depiction. On the right-hand side of the fourth double spread Prince Cinders and his fairy godmother (target domains) are represented metonymically through their lower legs and feet (head excluded), acting as the source domain (see Figure 3). The communicative reason behind this metonymy is to create irony, which arises from the clash between the reader's expectations (ideally, fairies are powerful and able to make magic spells) and what the metonymic elaboration highlights (Prince Cinder's fairy is incapable of making his desires come true). This is a clear case of situational irony (Ruiz de Mendoza \& LozanoPalacio, 2019), also known as intertextual irony in literary approaches (Díaz-Armas, 2006).

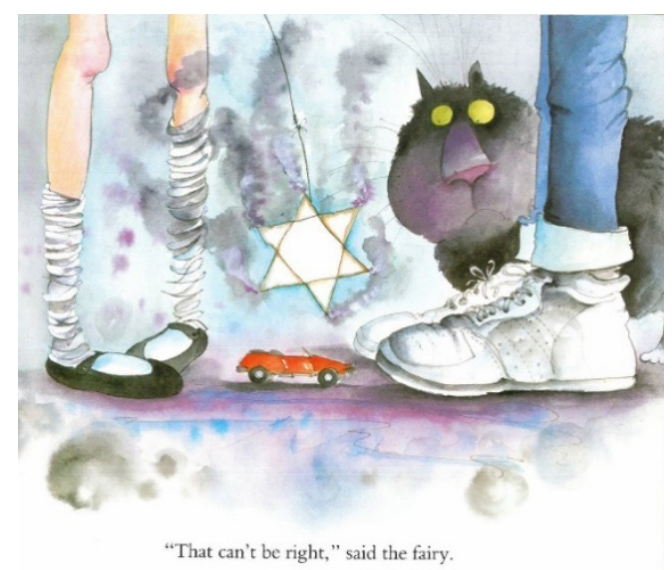

Figure 3: Prince Cinders's godmother's spell. Illustration from PRINCE CINDERS by Cole. Copyright @ P Putnamzooz. 
Through this monomodal visual metonymy Cole makes fun of Prince Cinders's godmother. The illustration shows that the empty can she tries to turn into a car to take the prince to the Palace disco is too small. After her magic spell the can becomes just a toy car, made clear by the depiction of the fairy magic wand and the two characters being so large that they go beyond the frames of the illustrations. Only part of their legs and feet can be appreciated. This metonymic depiction, together with another new metonymy, tails and back legs of an animal (source domain) standing for Prince Cinders's cat (target domain) in double spread six, contribute to creating irony in the story and making fun of traditional tales. Prince Cinders's cat speeds away after seeing the Prince transformed into a huge, hairy monkey. The cat even goes away from the dirty fairy. It seems that Prince Cinders's godmother is unable to produce a proper magic spell.

Six metonymic occurrences (four of them activated without a previous full depiction) have been found in 10,000 Dresses by Ewert and Ray. This story depicts a transgender experience in which a boy is not accepted by his parents and needs to find support outside his family environment. It recounts the story of Bailey who dreams about magical dresses every night. However, when he is awake, neither his mother, his father or his brother pay attention to his beautiful dreams. Then Bailey meets Laurel, an older girl who shares his interests. The two of them make dresses together. Laurel describes Bailey as the coolest girl she has ever met. In this context, the first metonymy identified in 10,000 Dresses, two arms and hands holding a pair of scissors (source domain) for Bailey's mother (target domain), introduces a new character in the story and contributes to emphasizing Bailey's mother's lack of attention and careless attitude to Bailey (double spread 4). The monomodal visual metonymy shows the female character involved in her own business. The text adds to the visual information that the mother is the kitchen cutting out coupons. Maybe, she is the owner of a clothes shop and is fixing the prices for the new season.

Once again, contrary to the expectation that complete manifestations of characters facilitate their identification to the young child and, thus, usually precede part-whole depictions, (Painter et al., 2013), Bailey's mother is activated for the first time through a part/whole metonymy. In fact, she is never depicted in full in the story, which reinforces the lack of contact and understanding between Bailey and his mom, who never pays attention to her son's true desires to wear a dress. This pattern is only broken at the end of the story, which I will refer to later.

A new metonymic depiction is found in the next double spread, part of the head, back and part of legs of a woman in a blue skirt (source domain) for Bailey's mother (target domain). She is facing Bailey. As her head and legs surpass the frames of the illustrations, she is depicted as a powerful woman, especially if compared with Bailey, represented as a small child who is trying to attract his mother's attention. The verbal mode plays a key role to understand the distance that is created in the illustration between mother and son. In fact, when Bailey tells his mom that he has dreamt about a dress, she does not give him the opportunity to talk about it and tells him to go away: 


\begin{abstract}
"Bailey, what are you talking about? You are a boy. Boys don't wear dresses!" "But... I don't feel like a boy." Bailey said. "Well, you are one, Bailey, and that's that! Now go away ... and don't mention dresses again! (10, 000 Dresses, double spread 5).
\end{abstract}

This uncaring attitude towards Bailey is also adopted by his father and brother. When the boy approaches his brother to tell him that he has dreams about dresses, Bailey gets a similar answer. His brother and friends are also represented metonymically without being previously depicted in full in double spread seven. The metonymy, part of trunks and legs of three people playing soccer (source domains) standing for Bailey's brother and his friends (target domains), helps to criticize Bailey's brother's lack of attention to Bailey's real desires. The brother is also involved in his own activity, with his friends and does not care about Bailey's feelings. In the next double spread Bailey's brother is also represented through another metonymy, arms and hands of a boy holding a football (source domains) for Bailey's brother (target domain). These new metonymic depictions highlight Bailey's brother's lack osensitivity towards the transgender boy. There is still no possibility of visual contact between the two characters, as the posture of the boy catching the ball suggests that he is not facing Bailey. In addition, the text contributes to highlighting Bailey's family's lack of support towards him, as it repeats practically the same words previously uttered by Bailey's mother in the previous double spreads. It is even more aggressive and his message is even threatening: "You dream about dresses, Bailey? That's gross. You're a boy!" "But..." Bailey said. "But nothing. Get out of here, before I kick you!"

Finally, Bailey decides to leave home and find the support he needs somewhere else. The text, referring to Bailey as a girl, announces: "Bailey ran and ran. She ran all the way to the end of the block, until she came to a house with a big blue porch" (double spread 11). A new metonymy, hands holding a needle (source domain) for Lauren, Bailey's new friend (target domain), is used to introduce a new character in the story, Lauren, an older girl who shares the same interests as Bailey. This monomodal visual metonymy creates expectations. Readers know that this new character does not belong to Bailey's family, as he ran away from home after being rejected by his mother, father and brother. It seems that Bailey has finally found the support and friendship he needs to be happy. In addition, as the text specifies, his new friend values Bailey's ideas and creativity to make new dresses.

At this point the illustrator breaks with the faceless character pattern adapted so far. Indeed, in the following double spread, the $12^{\text {th }}$, Lauren is shown in full in the visual mode after having been represented metonymically. This is the first time that, besides Bailey, who is always represented in full, Ray, the illustrator, activates a character's complete depiction. This establishes a contract with the members of Bailey's family, always involved in their own activity, and Lauren, who really supports and understands Bailey. The text announces that Bailey and his new friend, referring to them as the girls, 
"made two new dresses, covered with mirrors of all shapes and sizes" (double spread 12), dresses that reflect their own personality. So, it seems that the contrast between full and metonymic depictions is used to establish engagement (full depictions) and distance (metonymic depictions) in this picture book. Lauren is the only character in the story who accepts Bailey as he is, and she is represented in full in the last illustration, making eye contact with the viewer and holding hands with the young boy. All the other characters, Bailey's family members, are depicted metonymically, headless, and therefore unable to establish eye-contact with either the transgendered boy or the young reader.

Overall, visual metonymies seem to be pertinent tools used by illustrators in picture books featuring boys who do not conform to macho stereotypes, in order to promote social acceptance and gender equality ${ }^{4}$. These metonymic manifestations tend to be preceded by complete representations. However, there are also cases where a part-whole depiction of a character is activated before a full complete representation.

\section{Conclusions}

The aim of this paper was to prove whether and, if so, how visual metonymies, in combination with verbal language, contribute to challenging gender stereotypes in picture books featuring boys as main characters. The analysis shows that metonymic manifestations arise in the three picture books selected for study. From the illustrator's perspective, readers seem to have enough cognitive ability to make the inferences that part-whole depictions of characters may require when they have to track participants in the visual mode. These source-in-target metonymies (Ruiz de Mendoza \& Díez, 2002), typically realized by body parts and silhouettes, tend to be preceded by complete representations, as these aid recognition and identification. By means of these domain expansions, the illustrator highlights some relevant aspects of the characters involved in the plot, making them more noticeable to the young reader. That said, there are also cases where metonymies are activated without a previous depiction in full, essentially when the illustrator introduces a new character in the story and wants to create expectations at important moments in the narrative plot.

In addition, the analysis reveals that the nine metonymic representations identified in the picture books featuring boys may be decisive in the construction of gender roles and the challenge of gender stereotypes. They essentially contribute to putting the reader on the main character's side. Indeed, in combination with verbal language, they are used to: i. highlight the idea that children should always be proud of who they are,

\footnotetext{
4. As Moya-Guijarro (2013) points out, metaphors are not frequently used in children's picture books, as young children's cognitive abilities are still in the process of development and are not necessarily mature enough to understand the communicative potential of metaphors. Note that unlike metonymy, through metaphor a concept provides mental access to another phenomenon which belongs to a different conceptual domain.
} 
independently of their sexual orientation (10,000 Dresses), ii. ascribe negative qualities or attitudes to characters, essentially parents who do not accept their children whoever they are or whatever they want to look like (10,000 Dresses), iii. introduce new characters in the story and create expectations at important moments in the plot (Willy the Champ, 10,000 Dresses), iv. create irony and make fun of traditional stories (Prince Cinders) and, finally, v. suggest the idea that not all boys conform to macho stereotypes, but all of them deserve the respect of their peer group and families (10,000 Dresses, Willy the Champ).

This contribution has attempted to shed light on the use of visual metonymies in the genre of picture books and the discourse functions they fulfil in the specific narrative contexts where they are included. From the illustrator's perspective, young readers seem to be capable of tracking characters through the tales when some of their appearances are realized through part-whole metonymic representations. The inferrences young readers have to make to track part-whole depicted participants in picture books may contribute to the development of their visual literacy, which may become essential to understand discourses which attempt to make a better world and promote social acceptance.

\section{References}

Barcelona, A. (2002). Clarifying and applying the notions of metaphor and metonymy within cognitive linguistics: An update. In R. Dirven \& R. Pörings (Eds.), Metaphor and Metonymy in Comparison and Contrast (pp. 202-277). Berlin / New York: Mouton de Gruyter.

Barton, G., \& Unsworth, L. (2014). Music, multiliteracies and multimodality: Exploring the book and movie versions of Shaun Tan's The Lost Thing. Australian Journal of Language and Literacy, 37(1), 3-20.

Díaz-Armas, J. (2006). El contrato de lectura en el álbum: Paratextos y desbordamiento narrativo. Primeras Noticias, 222, 33-40.

Feng, D., \& O'Halloran, K. (2013). The multimodal representation of emotion in films: Integrating cognitive and semiotic approaches. Semiotica, 197, 79-100.

Forceville, C. (2009). Metonymy in visual and audiovisual discourse. In E. Ventola \& A. J. Moya-Guijarro (Eds.), The world told and the world shown: Multisemiotic issues (pp. 57-74). Basingstoke/New York: Palgrave Macmillan.

Forceville, C., \& E. Urios-Aparisi (Eds). (2009). Multimodal metaphor. Berlin/ New York: Mouton de Gruyter.

Halliday, M. A. K. (1978). Language as social semiotic: The social interpretation of language and meaning. London: Edward Arnold.

Halliday, M. A. K. (2004). An introduction to functional grammar. Third Edition. Revised by Christian M. I. M. Matthiessen. London: Edward Arnold.

Hamilton, M., Anderson, D., Broaddus, M., \& Young, K. (2006). Gender stereotyping and under-representation of female characters in 200 popular children's picture books: a twenty-first century update. Sex Roles, 55, 757-65. 
Hidalgo, L., \& Kraljevic-Mujic, B. (2011). Multimodal metonymy and metaphor as complex discourse resources for creativity in ICT advertising discourse. Review of Cognitive Linguistics, 9(1), 153-178.

Kress, G., \& van Leeuwen, T. (2006 [1996]). Reading images. The grammar of visual design. London: Routledge.

Lakoff, G. (1987). Women, fire, and dangerous things: what categories reveal about the mind. Chicago: University of Chicago Press.

Lakoff, G., \& Johnson, M. (1980). Metaphors we live by. Chicago: University Chicago Press.

Martínez Lirola, M. (2019). Approaching the construction of multimodal masculinity in a sample of picture books with two-men families. Asparkia, 34, 87-105.

McCabe, J., Fairchild, E., Grauerholz, L., Pescosolido, B., \& Tope, D. (2011). Gender in twentieth century children's books: Patterns of disparity in titles and central characters. Gender and Society, 25(2), 197-226.

Moya-Guijarro, A. J., \& Pinar Sanz, M. J. (2008). Compositional, interpersonal and representational meanings in a children's narrative. A multimodal discourse analysis. Journal of Pragmatics, 40, 1601-1619.

Moya-Guijarro, A. J. (2013). Visual Metonymy in children's picture books. Review of Cognitive Linguistics, 11(2), 336-352.

Moya-Guijarro, A. J. (2014). A multimodal analysis of picture books for children: A systemic functional approach. London: Equinox.

Moya Guijarro A. J. (2019). Textual functions of metonymies in Anthony Browne's picture books: A multimodal approach. Text \& Talk, 39(3), 389-413.

Painter, C., Martin, J., \& Unsworth, L. (2013). Reading visual narratives: Image analysis of children's picture books. London: Equinox.

Pinar, M. J. (Ed.) (2015). Multimodality and cognitive linguistics. Amsterdam / Philadelphia: John Benjamins.

Ruiz de Mendoza, F., \& Díez, I. (2002). Patterns of conceptual interaction. In R. Dirven $\&$ R. Pörings (Eds.), Metaphor and metonymy in comparison and contrast (pp. 489532). Berlin / New York: Mouton de Gruyter.

Ruiz de Mendoza Ibáńez, F., \& Lozano-Palacio, I. (2019). A cognitive-linguistic approach to complexity in irony: Dissecting the ironic echo. Metaphor and Symbol, $34(2), 127-138$.

Sunderland, J. (2012). Language, gender and children's fiction. London: Continuum.

Sunderland, J. \& McGlashan, M.(2012). Stories featuring two-mum and two-dad families. In J. Sunderland. Language, gender and children's fiction (pp. 142-172). London: Continuum.

Sperber, D., \& Wilson, D. (1985). Relevance: communication and cognition (Second Edition). Oxford: Blackwell. 
Taylor, F. (2003). Content analysis and gender stereotypes in children's books. Teaching Sociology, 31, 300-311.

\section{Picture books}

Browne, A. (2008 [1985]). Willy the champ. London: Walker Books.

Cole, B. (1997). Prince Cinders. New York: Putnam.

Ewert, M., \& Rex, R. (2008). 10.000 dresses. New York: Seven Stories Press. 